\title{
Resistance to Racial Equity in U.S. Federalism and its Impact on Fragmented Regions
}

\author{
Sheila Grigsby, $\mathrm{PhD}, \mathrm{MSN} / \mathrm{MPH}, \mathrm{RN}^{1}$ \\ Alicia Hernàndez ${ }^{2}$ \\ Sara John ${ }^{3}$ \\ Désirée Jones-Smith, MEd ${ }^{1}$ \\ Katie Kaufmann ${ }^{4}$ \\ Cordaryl Patrick, MPPA ${ }^{5}$ \\ Christopher Prener, $\mathrm{PhD}, \mathrm{MPH}^{6}$ \\ Mark Tranel, $\mathrm{PhD}^{1}$ \\ Adriano Udani, PhD, $\mathrm{MPA}^{1}$
}

${ }^{1}$ University of Missouri, St. Louis

${ }^{2}$ American Civil Liberties Union (ACLU) of Missouri

${ }^{3}$ Interfaith Committee on Latin America (IFCLA)

${ }^{4}$ Ready by 21 St. Louis at the United Way of Greater St. Louis

${ }^{5}$ St. Louis Economic Development Partnership

${ }^{6}$ Saint Louis University

The authors are grateful for Kiley Bednar, Iulia Fieser, Burnea Lester, Michael Marino, and the Community Innovation and Action Center (CIAC) at the University of Missouri, St. Louis in helping to produce the virtual town hall "Connect4" series and this manuscript that captures our discussions.

Author contributions: D.J.S. and A.U. designed process for obtaining academic-practitioner perspectives; S.G., A.H., S.J., K.K., and C.Pr. participated as panelists in virtual town hall discussion, and their statements were used for this commentary; C.P. and M.T. provided separate analyses; and D.J.S., C.Pr., M.T., and A.U. wrote the paper.

Corresponding Author: Adriano Udani, Department of Political Science, University of Missouri, St. Louis, One University Blvd. 347 Social Sciences Building, St. Louis, MO 63121.

Email: udania@umsl.edu

This manuscript is forthcoming in the American Review of Public Affairs. 


\begin{abstract}
In this commentary, we provide our ground-level observations of how the novel Coronavirus disease (COVID-19 or COVID) has exposed weaknesses in our federal system to respond to local communities, particularly Black and Latina/os who live and work in the St. Louis region. Our perspectives come from a virtual town hall hosted by the Community Innovation and Action Center (CIAC) at the University of Missouri, St. Louis on April 18, 2020. Based on these initial public discussions, we use St. Louis as a lens for arguing that that government's attenuated impact is not due to a natural disaster itself, but the inevitable result of race-based policies that had worked against Black peoples over generations. The real failure involves our federalist system's lack of a commitment to racial equity - when race no longer is used to predict life outcomes, and outcomes for all groups are improved - when designing the federal plan to respond to COVID-19 in local communities.
\end{abstract}

Keywords: racial equity, federalism, urban studies, COVID-19, public health 


\section{Resistance to Racial Equity in U.S. Federalism and its Impact on Fragmented Regions}

\section{Introduction}

Questions about federalism feel newly discovered after each major national crisis. Yet, we also feel that questions concerning race and racism, especially in public administration, do not receive the same rebirth. The inattention of race and racism in public administration scholarship has received much attention (Alexander, 1997; Witt, 2006; Stivers, 2007). Scholars have defined racism as an illusory ideological system of beliefs that maintain structures of social oppression (Shelby, 2002; Stivers, 2007). Racism also does not require racist actors, and can exist in systems and culture as well as with individuals, both unconsciously and consciously (Powell et al., 2006). Policymakers and public administrators are certainly not above racist motivations and decisions. Some have shown how they use their privilege to mask malicious administrative intent (Adams \& Balfour, 2004) while others have brought more attention to how administrators can rearticulate their decisions by publicly renouncing the exercise of discretion in favor of adhering to the letter of the law. As Camilla Stivers (Stivers, 2007) argued forcefully, "administrative practices can be infected with racism even though individual administrators do not bear conscious animus toward people of color. In this respect, racism, like administrative evil, is masked."

As we write this commentary in the midst of watching many United States communities muddle through and attempt to circumvent the extraordinary impact of COVID-19, it is frustrating to watch the Trump Administration refuse to equitably respond to local areas, forcing states and lower political subdivisions to fill in the gaps (Sawicky, 1999). Many conservatives 
have taken the pandemic to exemplify the strengths of American federalism; however, others have pointed to their longer-term movement to hollow out the state (Kreitner, 2020; Thompson, 2020; Mettler, 2010; Hacker, 2004) and develop a “fend-for-yourself” federalism (Walters, 1996) while other scholarship has shown that policy devolution has led to states developing welfare sanctions that disproportionately harm low-income Blacks ( $\underline{\text { Soss, Fording, \& Schram, }}$ 2011) and rely on highly discretionary and discriminatory enforcement of immigration laws that unfairly incarcerate Mexicans and Central Americans who are seeking refuge from violence (Gómez Cervantes et al., 2017). As such, many have concluded U.S. federalism is unfit to respond to a pandemic (Kreitner, 2020; Kilgore, 2020; Belz \& Sheiner, 2020; Cohen, 2020).

While we agree with these critiques, we take a different analytical frame of assessing failure. There has been an increasing growth in the number of events that could be declared national disasters, and therefore require federal intervention (Birkland \& DeYoung, 2011). We view the pandemic as no exception. We build upon others who have argued that government's attenuated impact is not due to a natural disaster itself, but the inevitable result of race-based policies that had worked against Blacks over generations (Stivers, 2007; Riccucci, 2009; Frymer, Strolovitch \& Warren, 2006; Smith (1999); Soss, Fording, \& Schram, 2011). The real failure of our federalist system is rooted in systemic racism and a resistance to racial equity. Too often, race - under the harmful language of "pre-existing conditions" - is used as a shorthand explanation to dismiss the dismal life outcomes and quality of life for Black people as inevitable and not a result of failed systems. Likewise, race is also used to explain away the lackluster preparedness and recovery of under-resourced communities after disasters. Complacency, based in white supremacy and disguised as pragmatism, leads to worse recovery outcomes not just for communities of color, but all marginalized members of historically disadvantaged groups post- 
natural disaster. By bringing this failure to the fore of public administration scholarship, we pose important implications for practice and scholarship. Racial inequity is glaringly central to the Trump Administration's response to state and local governments, and has led to an abandonment of constitutional and moral obligations to the equal treatment of people.

In this commentary, we provide our ground-level observations of how the novel COVID19 pandemic has exposed weaknesses in our federal system to respond to local communities, particularly Black and Latina/os who live and work in the St. Louis region. On April 18, 2020, the Community Innovation and Action Center (CIAC) at the University of Missouri, St. Louis hosted a virtual town hall, which connected academics with practitioners, community leaders, and advocates from different issue areas such as immigration, civil rights, education, economic development, and health. The objective of the town hall aimed to publicly share different perspectives on local, state, and federal social systems' capacity to meet the basic needs of historically marginalized groups.

We organize our commentary as follows. First, we establish an overview of the federal plan, its goals and objectives. As we argue, the Trump Administration's decisions lay bare how a commitment for racial equity was sorely missing from federal planning. We then utilize our ground-level observations in the St. Louis region - an area that is highly decentralized and spans over two different states - to show the consequences of an inattention to racial equity among federal leaders. Drawing from our own panelists' perspectives, we discuss severe economic and health consequences at the local level. After providing our critical analysis, we provide some concluding remarks on how practice can inform public administration scholarship. Ultimately, we elevate the work of others who (Lopez-Littleton \& Blessett, 2018, 454) advocate for teaching 
racial equity to the "next cadre of public administrators," who will be "a critical link in the government's response to meeting the needs of a diverse and changing citizenry."

\section{Racial Equity and Public Administration}

Public administration has certainly demonstrated a commitment to social equity (Fredrickson, 1990), but noted difficulty in its integration in the discipline (Riccucci, 2009; Svara \& Brunet, 2004; Durant \& Rosenbloom, 2017; Meier, 2015; Dahl, 1947). As Robert Durant and David Rosenbloom (2017) summarize, social equity is an "ought" rather than an "is."

Nevertheless, scholars have still provided guidance over what social equity looks like in public administration (Perry, 2005; Svara \& Brunet, 2004). Strikingly, racial equity is not mentioned; at best, it is wrapped into commitments to equal rights and protection and justice. It is often assumed or taken for granted that public administrators and servants will faithfully enforce the laws and set their own prejudices aside. Yet, naming racial equity as part of public administration and policymaking - as more than an aspirational goal - matters. Stivers (2007) outlines the precarious balance between the importance of frontline workers' discretion with much evidence that shows a pattern to such administrative judgments that is biased against Black people and the poor. Others (Gooden, 2014: 198) have also argued forcefully for bringing the importance of race to the forefront of public administration by asserting public sector personnel should "recognize and eliminate behaviors that impede racial equity."

Academic centers and foundations have provided guidelines for implementing racial equity. For example, the Local and Regional Government Alliance on Race and Equity (GARE) have put forth a theory of change (Curren et al., 2016) that: 1) uses a racial equity frame that clearly names and acknowledges the complicit role of government in oppression; utilizes definitions of inequity which recognize implicit and explicit bias as well as institutional and 
structural racism; and, envisions a new role for government; 2) builds organizational capacity and leadership from national to local levels that are committed to the breadth and depth of institutional transformation; 3) implements new policies and programs that are informed by datadriven processes; 4) partners with local and regional governments; and 5) communicate with urgency.

\section{The Federal Plan}

COVID-19 exposed the severe consequences of not integrating GARES's framework at higher-levels of U.S. federalism and administration. The U.S. government's plan (https://www.nga.org/coronavirus/\#federal) to respond to COVID-19 can be conceptualized through dominant policymaking components that others have used (Howlett \& Ramesh, 2003): agenda setting, policy formulation, adoption (or decision making), implementation and evaluation. These phases help to bring criticism of the federal response and the subsequent impact on states and localities into sharper focus. At the end of January 2020, from the first knowledge of the virus's spread across the globe through January, the way that the administration set the agenda for a COVID-19 response received much criticism, especially its cultural and racial tone deafness. For example, despite medical experts and evidence of the severe consequences of not taking COVID-19 seriously across the globe, the Trump Administration publicly treated the virus as a minor threat that was under control, and repeatedly assured the public that the risk to Americans was very low (Wallach \& Myers, 2020). Federal leaders also did nothing to acknowledge historical and evidence-based findings that show how the socioeconomic position, residence, and occupations of black and brown people make them more susceptible to infection (Cambria, Fehler, Purnell, \& Schmidt 2018; Purnell et al. 2018). 
Further, national leaders were silent on acknowledging that mistrust of government and health officials are rampant in communities of color. These initial ways in which Trump constructed the problem set the country off course and set local communities way behind in proactively responding to the disease at the ground-level.

The federalist structure itself also hinders local communities. Following the prescription of the federal system's tenets and presumed "lead response" requires more resources or power than local communities actually possess. In the context of federal inaction or support, a local community cannot actually lead in any real way. As the Trump Administration and allies did their best to irresponsibly frame COVID-19 as a foreign disease (insisting on calling it the Wuhan disease), it directed its attention to guarding national borders and regulating entrants, amplifying the sense of foreign threat and thereby motivating racist and ethnocentric reasoning and information seeking (Udani, 2018). Further, it also meant that Trump untethered the federal government from its executive branch responsibility to localities, especially economically depressed areas that needed external support, and further deepened distrust of government among residents of color.

Due only to public pressure, the Trump Administration was forced to formulate public policies to respond. Aligned with his campaign promise, Trump committed to utilizing ethnocentric principles and refused to address the pandemic through global partnerships. First, the Trump Administration determined that the U.S. would adopt an insular domestic approach to testing. The World Health Organization (WHO) distributed tests to dozens of laboratories around the world by early February. Yet, the administration and CDC decided to rely exclusively on domestically developed tests, which others have noted is consistent with past practice (Wallach 
\& Myers, 2020). The negative consequences of this decision were amplified when labs reported that the CDC kits were unusable (Cohen, 2020).

The Trump administration would also rely on private corporations, rather than develop a plan to utilize community-based organizations, which have stronger ties to black and brown communities. The $\mathrm{CDC}$ widened testing criteria at the end of February while the FDA were permitted to allow the use of non-approved tests with retroactive approval (Wallach \& Myers, 2020). As others have taken these to mean that the federal government signaled that it had begun to recognize and correct for the flaws in its testing regime (Wallach \& Myers, 2020), it actually further privileged the role of private corporations and wealthy foundations to drive the national response and made the federal government a more tangential partner in pharmaceutical and nonpharmaceutical suppression initiatives. What is more, the problem was further defined as an economic problem, not one of racial disparities nor systemic racism.

The federal government then started to adopt policies on how to respond to COVID-19 starting in March. In light of evidence of the economic impact, Congress responded with billions of dollars in relief aid (Wallach \& Myers, 2020). While these legislative actions amounted to historically large stimulus packages, they occurred without any critical discussions on equitable implementation for areas that are economically depressed, communities of color, and other markers of social disadvantage.

\section{Implementation and Policy Consequences}

The planned federal policy response to COVID-19 was not implemented to address systemic problems at the local level. The Trump administration would vacillate between the roles that federal, state, and local governments should play in a pandemic response. Even before 
COVID-19, studies have shown that state and county governments were neither prepared nor resourced to implement strategic plans to address global health crises (Holmberg et al., 2006). Thus, a variety of organizations ranging from state government agencies, municipalities, community health organizations, and hospital systems abandoned a shared strategy, and began to triage. The Trump Administration encouraged states to buy key equipment like personal protective equipment (PPE) and tests on the open market, rather than ensuring equitable distribution by releasing such items from the federal stockpile. However, several state's urgent and desperate searches for key resources on the open market were also impeded by the administration's own interventions and meddling. This catch-22 compounded the states' desperation for supplies and prompted increasingly martial responses from those states, rather than the traditional legal adjudications seen in the past. We can see this dynamic play out when Maryland held its PPE in an undisclosed location protected by the National Guard (Rector, 2020). Likewise, Massachusetts conducted independent international trade to obtain PPE from China (McKinley Becker, 2020). This emphasis on capital competition has tangible effects on regions and localities who have been regularly under resourced because of racial inequity.

Furthermore, the lack of racial equity in our federalist system eventually manifests as severe social and economic consequences in regions like St. Louis that already have suffered from decentralized systems that marginalize the poor and communities of color. Others have suggested that the absence of discussions about race and racism - or, rather, taking such topics for granted (Lopéz-Littleton, \& Blessett 2018) - can debilitate public sector organizations and undermine progress toward achieving racial equity (Gooden, 2014). Following, we discuss our 
ground-level observations in three areas pertinent to a racial equity framework: health, data collection, and partnerships.

\section{health.}

In many ways, St. Louis is a useful case to critically examine how the Trump Administration's response within our federal system has failed to meet constitutional prerogatives of equal treatment. Regional agreements do not tend to work when everyone is facing a crisis at the same time. The region is an exemplar of the complicated terrain of decentralized government, which itself has been shaped by white flight from St. Louis City and a disinvestment in Black neighborhoods (Johnson, 2020). Within the urban core of the region, St. Louis City has been separated from St. Louis County since the 19th century in what locals term the "great divorce." St. Louis City itself is the equivalent of a county. In St. Louis County, fragmentation is multiplied by the presence of 92 different municipalities. Moreover, the St. Louis metro straddles two different states. The current configuration of St. Louis's metropolitan statistical area includes a total of sixteen counties, eight of which lie in Illinois, and eight in Missouri. The Missouri side of the metro, which lies to the west of the Mississippi River, has a much larger population, but both have significant rural and exurban areas. There are some intraregional institutions, like the East-West Gateway. Overall, though, a bi-state infrastructure is limited.

With limited attention to racial equity in the major stages of the policymaking process, health outcomes succumb to prevailing inequalities that are held in place by status quo social structures. Fragmentation, both between the Missouri and Illinois sides of the metropolitan area 
and within these regions, has affected the region's COVID-19 response. The Missouri and Illinois halves of the metro have been under different sets of stay-at-home orders, with Illinois's being longer than Missouri's. Similarly, within the Missouri half of the metro, St. Louis City and County have had dramatically more stringent social distancing and stay-at-home policies than the other counties in the metro area. Coordination, except for the collaboration between the City and County, has been limited.

\section{Figure 1. Reported COVID-19 Cases in St. Louis Metropolitan Area}

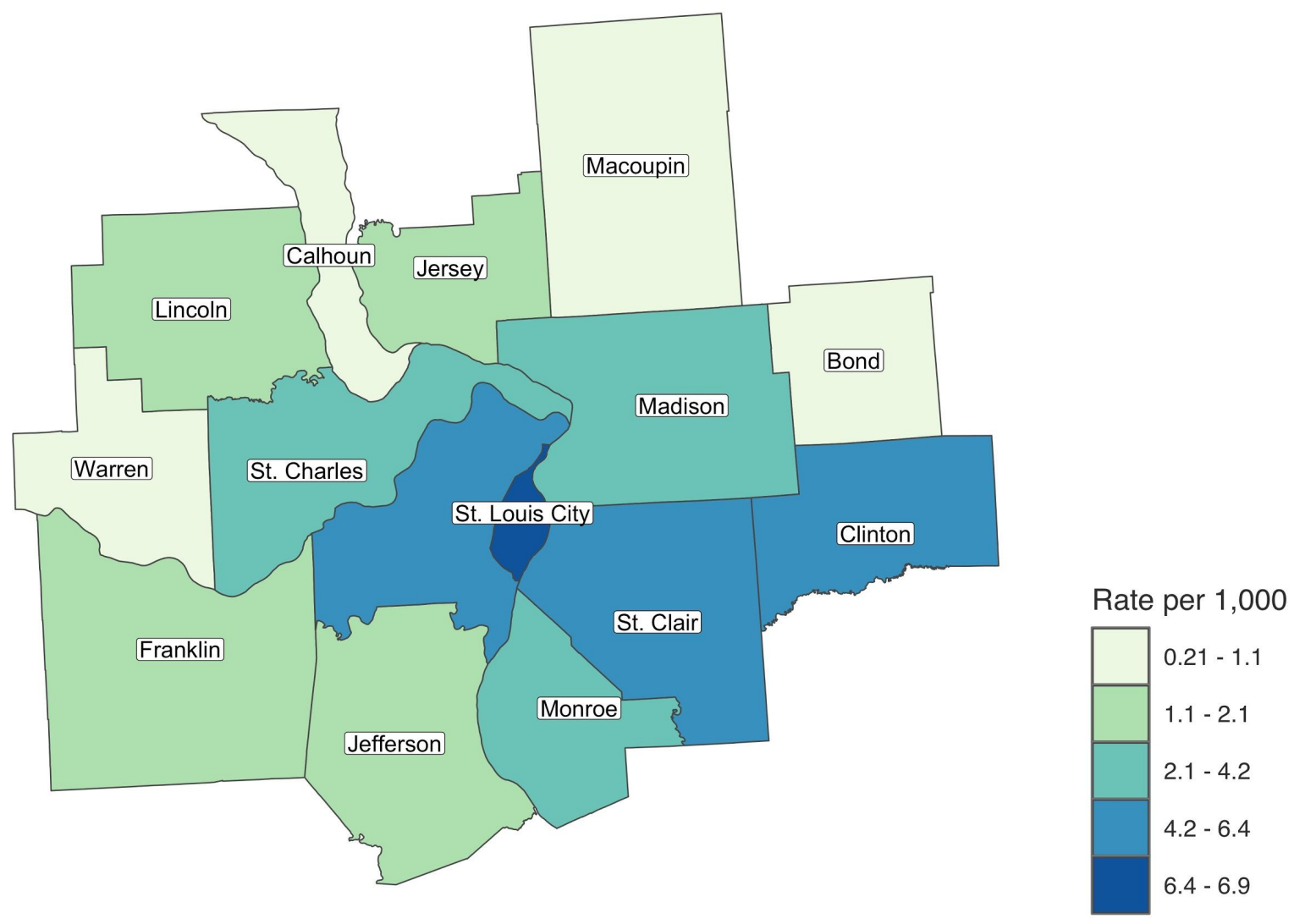

Compared to other metropolitan areas in Missouri, the St. Louis metro area itself has had the largest number of COVID-19 cases and the highest rates of infection throughout much of the 
outbreak. Within the St. Louis metro, infection rates have been largely focused in the two counties that form the urban core - St. Louis City and St. Louis County. However, the next highest infection rates include St. Clair, Monroe, and Clinton counties, which all lie across the state border in Illinois. This geographic pattern reflects the challenging nature of COVID-19 response here. Regional fragmentation has meant little coordination between the counties with the highest infection rates because they lie on opposite sides of the Missouri river.

Figure 2. Reported COVID-19 Cases by St. Louis Zip Code Tabulation Areas (ZCTAs)

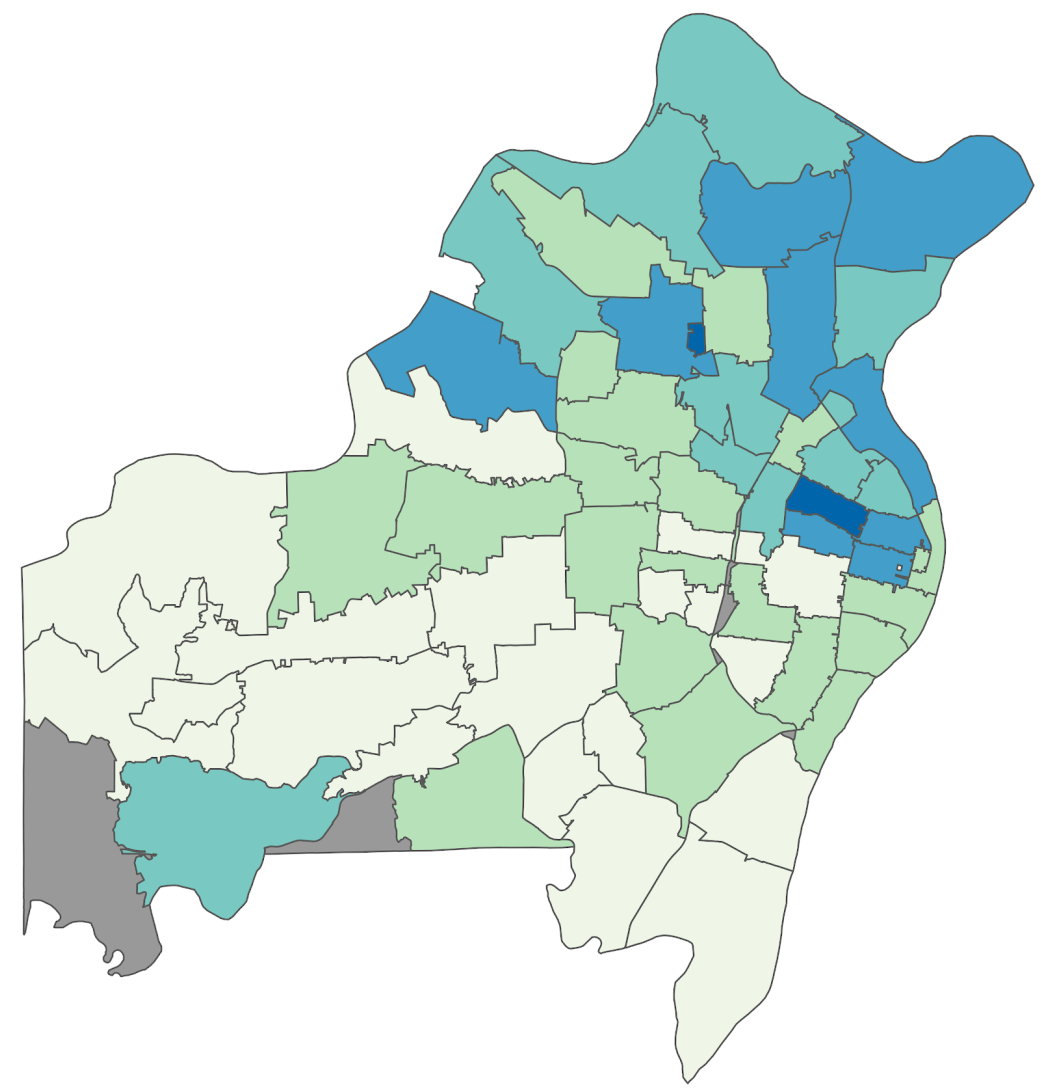

Rate per 1,000

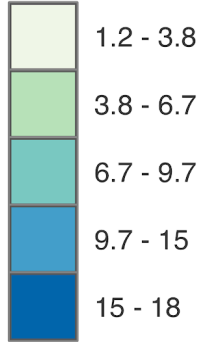

Even with coordination between the two most populated entities, systemic differences in the availability of services has meant that there is also important sub-county variation both in infection rates and the COVID-19 response. Areas of North St. Louis County and North St. 
Louis City, both centers of the Black community regionally, have had the highest rates of infection. The history of these areas (Purnell, Camberos, \& Fields 2014; Cambria, Fehler, Purnell, \& Schmidt 2018; Gordon 2008, 2019) is one of persistent segregation and deliberate policy attempts to further marginalize Black St. Louisans. Significant structural barriers existed prior to the COVID-19 outbreak for Black residents in terms of health, employment, and governmental services. Some of the most egregious practices gained national attention after Michael Brown's death in Ferguson in 2014, which shone a light on the financial practices of cash-starved small municipalities that turned to ticketing and warrants to pad flagging municipal budgets.

It comes as no surprise, then, that the patterns in poor health that existed prior to COVID19 appear to persist with COVID-19 as well (Purnell, Camberos, \& Fields 2014). Within both the City and the County, Black peoples have several times higher rates of infection and death from COVID-19 than their white and Asian neighbors. Municipal fragmentation means that Black communities in St. Louis have struggled to gain access to testing, and are at a greater risk for ill consequences from not just the virus itself but the economic ramifications of prolonged stay-athome orders. Local health departments were called into action and imposed their own sheltering orders, which came weeks prior to Missouri's state order. Federally-qualified health centers like Affinia and Care St. Louis had open sites and People's Health Center also provided testing.

Nevertheless, the lack of coordination and consistent messaging in a decentralized system contributed to unacceptable delays in testing sites in North St. Louis City and St. Louis County municipalities with a high proportion of Black residents. The Trump Administration's response plan failed to directly deal with the reality of many local public health systems. Missouri's public 
health surveillance systems have not been adequately prepared to deal with such a long running and fast moving public health crisis.

The decentralized structure has indeed complicated distributing resources to states; but, what we have observed, it has been further complicated with ushering resources/messaging across multiple jurisdictions and state actors. Missouri's decision not to expand Medicaid continues to greatly impact individuals and families. Many do not have health coverage. And the messages from the media to the public have directly instructed individuals to go to the emergency room if they are experiencing symptoms. The directions have also been to call your doctor. Yet, what if you don't have a doctor? What if these two options are not available to you? What is the third option? These questions, which pose more grave consequences for communities of color, have not been clearly discussed or put forward. To date, the messaging is still not clear about what to do if you're uninsured or under-insured, who are severely susceptible to infection.

Relying on local responses to COVID-19 without much federal support imposes severe costs and stress on home health care providers, who are disproportionately immigrants and women of color. Few have been trained or prepared to operate long term with this level of infectious illness out in the community. When their job requires them to enter patients' houses to provide care, they do not have the ability to distance themselves from patients nor do they have access to the same quality of PPE. Aside from the immediate impact of infection, there is also the long-term question of burnout among emergency medical service (EMS) providers, which is already a big issue, particularly in the city of St. Louis. The city has a shortage of paramedics, in part due to the level of gun violence that they regularly treat in our community. As we continue with these status quo arrangements of providing care and slowly inching toward recovery, 
communities will see greater problems arise like compassion, fatigue, and other problems that will impact our healthcare system for many years to come.

\section{data sharing.}

Testing and reporting also falters in fragmented municipal systems. The St. Louis County and St. Louis City health departments should be the touch points for reporting and testing. Instead, they report to the state who have internal reports to the CDC. When testing commenced, the state health department distributed and collected the test kits, in order to maintain a sense and control of the numbers. As this pandemic continued, though, it became clear that it needed to drastically increase testing. This presented two main problems. One, the state did not have sufficient resources and testing kits to do so. Second, the state health department continued to require private labs, physicians, and other health centers to report cases, even though their priority is to test. Those test results are going to the individuals, but they are not necessarily reporting back to the state health department. The disconnect between the state, county, and the city underscores weak infrastructure and old "Great Divorce" fault lines, that undermine initiatives to share and communicate data. While the city and the county in St. Louis in particular have been sharing (if belatedly) data on racial disparities, sending that data up to the state level has been a continual challenge and the state has yet to report data on the race of COVID patients.Yet, as others have illuminated about implicit or unconscious racist undertones in administrative decisions (Stivers 2007), we also remain concerned if the state actually is committed to gaining accurate data on race.

In responding to COVID-19, allies of marginalized populations in local communities then must balance two calls to action: one to the nation and one to combating systems of oppression. This impacts how localities have tested and reported COVID cases and deaths. From a practical 
standpoint when responding in real-time during a pandemic, the priority is to count the cases and worry about getting the data or the rest of the information later. Yet, this has created an imbalance and delay on how COVID-19 has impacted communities of color. When we think about numbers and how they're coming in the aggregate, populations that are disproportionately impacted often get subsumed, which perpetuates a misperception that those groups are not impacted, or worse, not deserving enough for attention and concern. We believe this is entirely attributed to federal requirements of reporting COVID-19 infections and deaths, which incentivize total aggregate numbers. Understanding the statistics of COVID-19's impact monolithically can erase historically marginalized groups from public discourse. In our region, policymakers and leaders have not given equitable attention to the elderly, homeless or immigrant populations. Instead, these populations are wrapped into other mainstream categories such as the uninsured without giving proper attention to how mental health, housing, citizenship, or language imposes cumulative disadvantages. What is more, the current level of testing is only reaching those people who have been extremely sick and those who have been persistent enough to get a test.

\section{partnerships.}

An inattention to racial equity in federalist systems also forces local actors to fill in service gaps ( $\underline{\text { Sawicky, 1999)}}$, which imposes more time and resource demands on those actors who are already operating beyond their own capacity. Greer and Jacobson (2010) also note that federalist systems promote dead zones: where the problem is that the federal government won't act while states can't act. The College of Nursing (CON) at the University of Missouri, St. Louis (UMSL) emptied its lab space and shared PPE with local hospitals in response to the needs of the community. In addition, CON students and faculty are helping to respond to the pandemic by 
working with local government agencies such as the St. Louis County Health Department to assist with contact tracing and providing temperature checks to drivers and factory workers at private corporations such as Amazon.

Further, the federalist structure also leaves it up to local advocates to "clean up the mess" that punitive federal policies intentionally leave behind. A day before our panel discussion, the Trump administration extended border restrictions, which allowed border agents to expel all migrants apprehended without the fear of screening required under U.S. law. The ACLU of Missouri scrambled to respond to President Trump's late night tweets about temporarily suspending all immigration. While it was later revealed that Trump scaled back the executive order to only limit new green cards, the executive order was still difficult to decipher. We anticipate will complicate the process of gaining lawful status for people who started this process before the pandemic and also lead to more scrutiny and ambiguity that will make it more difficult for naturalized citizens to vote in November.

The ACLU of Missouri also works to decrease the number of people who are incarcerated and detained by pushing sheriffs, prosecuting attorneys, and elected officials to grant release consideration for people who are being held on cash bail, elderly, immunocompromised, pregnant or anyone else who poses a minimal risk to the community. This has led to some jail releases of incarcerated people, but progress is difficult to track as it has been challenging to get exact numbers from jails in regards to releasing numbers on those in custody under the U.S. Immigration and Customs Enforcement. We have also seen prosecuting attorneys in our St. Louis area who have been receptive to special releases. The ACLU has also been working on helping with the delivery of groceries, supplies, and navigating the healthcare system. Work has also been done to bring language justice. There were delays in translating 
information to the region's immigrant and refugee communities with details about how to practice physical distancing and proactive health maintenance. In response, bilingual advocates and volunteers stepped up to serve as interpreters on emergency telephone hotlines for people who needed it.

The pandemic also exposes the absence of nationally unified policy systems, such as one focused on child development and well-being. The core of such a system should be the K-12 education in our communities as well as educational opportunities for training and career readiness for young adults. Unfortunately, the pandemic has imposed much stress on each of those education systems, and also revealed that they are rather insulated pipelines. Early childhood is a very fragmented system, in which programming is provided by different entities from women who own small businesses out of their homes, to large nonprofit centers, and even church- or school-based programs. They are also governed by a very complicated set of regulations from the state and local level, let alone shelter-in-place orders. For example, funding is certainly a huge challenge right now, because much of early childhood programming receives state and federal funding that is contingent on attendance. Currently, attendance is seriously limited if not suspended indefinitely in the K-12 space.

Our social systems are failing to respond to people with limited resources. The CARES Act made changes to tax law to enable nonprofit organizations with greater ability to solicit contributions and created a loan/grant program to enable nonprofits to retain staff. The tax law changes are a weak federal response as the economic consequence of COVD-19 is a recession which will make nonprofit contribution solicitation very difficult. Short term analysis of the implementation of the Paycheck Protection Program has documented a number of challenges and unintended consequences. The funding allocated in the Coronavirus Aid, Relief, and Economic 
Recovery (CARES) Act was fully committed in just 13 days, there was debilitating confusion among applicants, banks, and the Small Business Administration regarding the process of applying for funds, $\$ 10$ billion of the funds allocated to the program went to banks for loan processing fees, and most infamously, a substantial portion of the allocated funds went to corporations, not actual small businesses. The COVID-19 federalist lesson learned here is that sometimes federal action is only marginally better than federal inaction. As municipalities provide many services what is often missing is the subsequent responsibility of the federal government: if states are unable to arrive at satisfactory solutions, then responsibility should shift to the federal government (Leon-Moreta, 2018).

Some families don't even qualify for governmental aid or assistance, because of grant and funding restrictions to nonprofits, or because of certain status or needed documents. As the Trump Administration has insisted that the federal government has no responsibility to the states, community advocates were activated to rethink and redesign how funds are collected and allocated. One example in our region is the idea of mutual aid. Rather than giving to an organization, mutual aid organizers wanted to build a structure that allows financial solidarity. This is entirely different than the dominant needs-based structure in our federalized system of social assistance. Financial solidarity is based on the idea that people know what they need best. The primary guiding value is distributing funds based on equity, trust and urgency. The funds are received and distributed out of within a week based on people's own self-described needs, however expressed.

\section{Discussion}

At best, public administration considers racial equity as a normative and aspirational goal. It is wrapped into social equity, one of the three pillars of public administration. The local 
response, as others have argued (Stivers, 2007), aims to restore equity, subsequently making equity an afterthought. Racial equity sits in a precarious position in America that has always been uneasy about its federalist's structure, which has been administered as more of an art than a science. After all, at its core, federalism is an attempt to use seemingly opposing ideas to force a balance of powers.

The focus of our commentary has centered on how a lack of a racial equity lens at higher levels of the U.S. federal system has severe consequences at the local level, especially in a highly decentralized and fragmented political system like the St. Louis region. At least in our region and we surmise in others, the framework of federalism has been politically constructed as a narrative of allowing local actors to decide what is best for its constituents. We argue this largely misses the mark, as this narrative has been used against historically disadvantaged groups and for ensuring that white supremacist principles are not challenged or abolished (Powell [sic] et al. 2006). The question of how appropriate it is to use federalism to influence issues of moral significance is reflected in questions on school desegregation, busing, and other federal laws that sought to expand the groups considered to be first class citizens. Federalism has been an obstacle to welfare state growth and social justice (Immergut, 1992; Manza, 2000: 305 - 306) while others have examined the relationships between decentralized governance and the punitive treatment of communities of color (Riker, 1964; Schattschneider, 1960).

The part of federalism that gets overlooked is the incentivizing of local innovation and collaboration, which is part of a racial equity framework. In many ways, our region is being saved due to local actors looking for and forging opportunities for community partnerships, racial equity experts naming the complicit role of government in systems of inequality, 
innovative policy responses, and sharing of data and resources, and collaboration that have arisen in the absence of federal investments or leadership.

But we ask: why must we rely on community leaders and allies of historically disadvantaged groups to take the charge of using a racial equity lens? Doing so, imposes further constraints and stressors on personnel who are operating beyond capacity in battling injustice. We recommend initiating discussions about racial equity among elected leaders and administrative officials so that they incentivize community partnerships and utilize local expertise up front, and not wait until the end and hope that under-resourced and over-capacity organizations will reach out to one another. In sum, racial equity should be considered as a pillar of public administration (Fredrickson, 1990); if not, disentangled from a general goal of social equity; and, used to examine existing pillars of the economy, efficiency, effectiveness, and social equity under the auspices of anti-bias and anti-racism principles. Yet, Victor Thompson's ( $\underline{1975})$ question stands for racial equity: whose pillar should this be — academics', practitioners', elected officials', [or] we the people's? To begin to answer such a question, we propose like others have reframing racial equity from an only an ideal, a buzzword, or singular term to a methodology and its own logic of social inquiry, planning, and management. 


\section{References}

Adams, G. B. \& Balfour, D.L.(Eds.). (2004). Unmasking Administrative Evil. (Rev. ed.). Armonk, NY: M.E. Sharpe.

Alexander, J. (1997). Avoiding the issue: Racism and administrative responsibility in public administration. American Review of Public Administration, 27(4), 343-61.

Belz, S. \& Sheiner, L., (2020, March 23). How will the coronavirus affect state and local government budgets? Brookings Retrieved from website: https://www.brookings.edu/blog/upfront/2020/03/23/how-will-the-coronavirus-affect-state-and-local-government-budgets/ Birkland, T.A. \& DeYoung, S.E. (2011). Emergency response, doctrinal confusion, and federalism in the Deepwater Horizon oil spill. Publius: The Journal of Federalism, 41(3), 471-493.

Cambria, N., Fehler P., Purnell J.Q., \& Schmidt B. (2018). Segregation in St. Louis: Dismantling the Divide [brochure]. St. Louis, MO U.S.A.: Washington University in St. Louis. Retrieved from: https://cpb-usw2.wpmucdn.com/sites.wustl.edu/dist/3/1454/files/2018/06/Segregation-in-St.-LouisDismantling-the-Divide-22ih4vw.pdf

Cohen, J. (2020, February 28). The United States badly bungled coronavirus testing — but things may soon improve. Science. Retrieved February 28 2020, website: https://www.sciencemag.org/news/2020/02/united-states-badly-bungled-coronavirustesting-things-may-soon-improve 
Curren R., Nelson, J., Marsh, D.S., Noor, S., \& Liu, N. Racial Equity Action Plans, A How-to Manual.[Brochure].(2016) Berkeley, CA: Haas Institute for a Fair and Inclusive Society, University of California, Berkeley.

Dahl, R. A. (1947). The science of public administration: Three problems. Public Administration Review, 7(1), 1-11.

Durant, R. F., \& Rosenbloom, D. H. (2017). The hollowing of American public administration. The American Review of Public Administration, 47(7), 719-736.

Frederickson, H. G. (1990). Public administration and social equity. Public Administration Review, 50(2), 228-37.

Frymer, P., Strolovitch, D. Z., \& Warren, D. T. (2006). New Orleans is not the exception: re-politicizing the study of racial inequality. Du Bois Review: Social Science Research on Race, 3(1), 37-57.

Gómez Cervantes, A., Menjívar, C. \& Staples, W.G. (2017). “Humane” immigration enforcement and latina immigrants in the detention complex. Feminist Criminology, 12(3), 269292.

Gooden, S. (2014). Race and Social Equity: A nervous area of government. Armonk, New York: M.E. Sharpe.

Gordon, C. (2008). Mapping decline: St. Louis and the fate of the American city. Philadelphia, PA: University of Pennsylvania Press.

Gordon, C. (2019). Citizen Brown: Race, democracy, and inequality in the St. Louis suburbs. Chicago, IL: University of Chicago Press.

Greer, S. L., \& Jacobson, P. D. (2010). Health care reform and federalism. Journal of Health Politics, Policy and Law, 35(2), 203-226. 
Hacker, J. S. (2004). Privatizing risk without privatizing the welfare state: The hidden politics of social policy retrenchment in the United States. American Political Science Review, 98(2), 243-260.

Holmberg, S. D., Layton, C. M., Ghneim, G. S., \& Wagener, D. K. (2006). State plans for containment of pandemic influenza. Emerging Infectious Diseases, 12(9), 1414-1417. https://doi.org/10.3201/eid1209.060369

Howlett M. \& Ramesh, M. (2003). Studying public policy: Policy cycles and policy subsystems. Oxford, UK: Oxford University Press.

Immergut, E.M. (1992). Health politics: Interests and institutions in western europe. Cambridge, UK: Cambridge University Press.

Johnson, W. (2020). The broken heart of America. New York, NY: Basic Books.

Kilgore, E. (2020, April 1). Federalism Is a Bad Prescription for Handling the Coronavirus Crisis. NYMagazine Intelligencer. Retrieved May 15, 2020, website: https://nymag.com/intelligencer/2020/04/federalism-is-a-bad-prescription-for-handlingcoronavirus.html

Kreitner, R. (2020, April 1). When Confronting the Coronavirus, Federalism Is Part of the Problem. The Nation. Retrieved May 15, 2020, website: https://www.thenation.com/article/politics/federalism-coronavirus-problem-government

Leon-Moreta, A. (2018). Functional responsibilities of municipal governments. The American Review of Public Administration, 48(1), 18-32.

Lopez-Littleton, V., Blessett, B., \& Burr, J. (2018). Advancing social justice and racial equity in the public sector. Journal of Public Affairs Education, 24(4), 449-468. 
Manza, J. (2000). Race and the underdevelopment of the American welfare state. Theory and Society, 29(6), 819-832.

McKinley Becker, K. (2020, April 2). “No Days Off”: Patriots' Plane delivering over 1.7 Million N95 masks. NBCBoston Retrieved website: https://www.nbcboston.com/news/sports/patriots/patriots-plane-bringing-medicalsupplies-to-massachusetts-report/2101163/

Meier, K. (2015). Proverbs and the evolution of public administration. Public Administration Review, 75(1), 15-24.

Mettler, S. (2010). Reconstituting the Submerged State: The Challenges of Social Policy Reform in the Obama Era. Perspectives on Politics, 8(3), 803 - 824.

National Governors Association. (2020). Coronavirus: What you need to know. https://www.nga.org/coronavirus/\#federal

Perry, S. (2005). Social equity for the long haul (Doctoral dissertation Virginia Polytechnic Institute and State University, Blackberg, Virginia, U.S.A.). Retrieved from http://scholar.lib.vt.edu/ theses/available/etd-11282005-141500/unrestricted/SLWPerryDissertation.pdf

Powell, J., Jefferies, H.K., Newhart, D.W., Steins, E. (2006). Towards a transformative view of race: The crisis and opportunity of Katrina. In Hartman, C. \& Squires G.D. (Eds), There Is No Such Thing as a Natural Disaster: Race, Class, and Hurricane Katrina (pp.59-84). New York, NY: Routledge.

Purnell, J. Q., Goodman, M., Tate, W. F., Harris, K. M., Hudson, D. L., Jones, B. D., ... \& Gilbert, K. (2018). For the sake of all: civic education on the social determinants of health and health disparities in St. Louis. Urban Education, 53(6), 711-743. 
Purnell, J.Q., Camberos G. J., \& Fields R. P. (Eds.). (2014). For the Sake of All: A Report on the Health and Well-Being of African Americans in St. Louis and Why It Matters for Everyone. [Brochure] St. Louis, MO U.S.A.: Washington University in St. Louis: Retrieved from: https://cpb-usw2.wpmucdn.com/sites.wustl.edu/dist/3/1454/files/2018/06/FSOA_report_217zd1xm.pdf

Rector, K. (2020, April 6). 'Not an ideal solution': Maryland National Guard members advised to make their own cloth masks. Baltimore Sun. Retrieved from website: https://www.baltimoresun.com/coronavirus/bs-md-national-guard-masks-202004065cx73sftqrf3jgjgx4gzclfqya-story.html

Riccucci, N. M. (2009). The pursuit of social equity in the federal government: A road less traveled?. Public Administration Review, 69(3), 373-382.

Riker, W. H. (1964). Federalism: origin, operation, significance. Boston, MA: Brown Little.

Sawicky, M. B. (1999). The end of welfare? Consequences of federal devolution for the nation. Armonk, N.Y.: M.E. Sharpe.

Schattschneider, E. E. (1960). The Semisovereign people: A realist's view of democracy in America. New York: Holt, Rinehart, and Winston.

Shelby, T. (2002). Is racism in the "heart"? Journal of Social Philosophy, 33(3), 411-20.

Smith, R.A. (1999). Racial differences in access to hierarchical authority: An analysis of change over time, 1972-1994. The Sociological Quarterly, 40 (3), 367-395.

Soss, J. Fording R.C., \& Schram, S.F. (2011). Disciplining the poor: Neoliberal paternalism and the persistent power of race. Chicago, IL: University of Chicago Press.

Stivers, C. (2007). "So poor and so black": hurricane Katrina, public administration, and the 
issue of race. Public Administration Review, (67), 48-56.

Svara, J. H., \& Brunet, J. R. (2004). Filling in the skeletal pillar: Addressing social equity in introductory courses in public administration. Journal of Public Affairs Education, 10(2), 99-109.

Thompson, V. (1975). Without sympathy or enthusiasm. Tuscaloosa, AL: University of Alabama Press.

Thompson, D. (2020, March 14). America Is Acting Like a Failed State. The Atlantic. Retrieved from website :https://www.theatlantic.com/ideas/archive/2020/03/america-isnt-failing-itspandemic-testwashington-is/608026/

Udani, A. (2018). Inferring what hardliners would do: assessing factual knowledge of state policies on immigrant treatment in the US. Politics, Groups, and Identities, 6(4), 631-649.

Wallach, P. A. \& Myers, J. (2020, March 31). The federal government's coronavirus actions and failures. Brookings. Retrieved from website: https://www.brookings.edu/research/thefederal-governments-coronavirus-actions-and-failures-timeline-and-themes/ Walters, J. (1996). Cry, the Beleaguered County. Governing, August, 31-37.

Witt, Matthew T. (2006). Notes from the margin: Race, relevance, and the making of public administration. Administrative Theory and Praxis, 28(1), 36-68. 